\title{
Language aspects in English for tourism class
}

\author{
Rifky Dora Wijayati ${ }^{\mathrm{a}, 1, *}$, Khafidhoh ${ }^{\mathrm{b}, 2}$ \\ ${ }^{a}$ Southwest University, Chongqing, China \\ ${ }^{\mathrm{b}}$ Universitas Ahmad Dahlan, Jl. Ringroad Selatan, Kragilan, Tamanan, Kec. Banguntapan, Bantul, Daerah Istimewa Yogyakarta 55191, Indonesia \\ ${ }^{1}$ rdw.wijayati@gmail.com*; ${ }^{2}$ khafidhoh@ @bi.uad.ac.id \\ * corresponding author
}

\section{ARTICLE INFO}

\section{Article history}

Received 4 December 2019

Revised 1 March 2020

Accepted 8 August 2020

Available Online 15 January 2021

Keywords

language aspects

English

tourism

\begin{abstract}
English for Tourism (EfT) class for higher education is a means of response to Industrial Revolution 4.0 era. Besides, it is also a collaborative field between English language and Tourism. For the subject, In English Education Department which mostly focuses on language instruction, the lecturers are expected to formulate the comprehensible materials to facilitate the instructional process. Thus, several related aspects should be considered in formulating the instructional design, including developing the materials. Then, the instruments to gain the data about the needs analysis are also important factors to make sure that the instructional design really meets the needs. As the research focuses on the language aspect in EfT class, specific expressions will be the answers for the big question which becomes the starting point of this research. It will be the basis in formulating the appropriate materials for the instruction.
\end{abstract}

This is an open access article under the CC-BY-SA license.

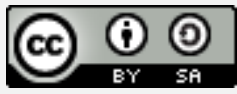

\section{Introduction}

Local wisdom becomes the urgent consideration in developing the curriculum in English Education Department of Universitas Ahmad Dahlan (PBI UAD). Since Yogyakarta is well-known as a tourism city, English for Tourism (EfT) becomes one of the subjects in PBI UAD curriculum. EfT is the preliminary subject for the next subject which is Practicum on Tourism (PoT). Thus, EfT class should give the students a bunch of information related to the Tourism industry, especially in Yogyakarta. It gives the students background knowledge to activate in doing the activities in PoT Class.

It is an interesting challenge for the lecturer to develop the comprehensible instructional design for the student so that the learning outcomes can be reached well. In general, there are two aspects to cover in the instructional design which are language and business aspects. In this occasion, the researcher focuses on the language use, especially in English. There should be an analysis on that topic. Thus, the researcher is interested in conducting a research on Language Assessment in EfT class.

\subsection{Tourism}

Damanik and Weber (2006: 11) propose that tourism offers two main commodities which are products and services. Tourism product means any product offered in the tourism industry while tourism services are related to the services that can be enjoyed in tourism activities. Tourism products and services cover so many things, especially in this dynamic era. The product can be from traditional foods to digital storyteller. Then, the services can be from hotel services to campervan services. All is used to refresh the costumers' mind as the outcome of the tourism industry. 


\subsection{Needs Analysis}

Day and Krzanowski (2011: 9) said needs analysis is comprehensive procedures to identify the students' profile, needs, and wants. Next, Richards (2001: 52) told that the aim at conducting needs analysis is understanding the students' needs, the appropriate instructional design, the materials' degree of necessary, the students' lacks and the gap between the materials and the students' understanding. In conclusion, needs analysis is a set of comprehensive procedures which play significant roles to identify the students' needs, wants, and lacks and the information is highly needed to develop an effective, efficient, comprehensive, and fun instructional design.

The needs analysis is classified into two. They are learner needs and learning needs (Hutchinson and Waters, 1987; Cahyo et al, 2019; Fatimah, 2018). Learner needs are related to the materials' degree of necessity, the students' lacks and wants while the learning needs are related to the support system for the teaching and learning process, such as the facilities, instructional methods, time allocation, etc.

\subsection{English for Tourism}

English, as one of the international languages, plays the key role in several aspects of both global community and communication. Especially in the tourism industry, it is significantly needed to communicate, negotiate, and execute transactions between the tourists and the tourism employees (Prachanant, 2012: 117).

Considering its characteristic, English for Tourism is a branch of English for Specific Purpose (Kusumawati, 2018; Mahendra, 2020; Prachanant, 2012; Sholikhi, 2020). In this case, it involves various expressions which belong to language for hospitality (Blue \& Harun, 2003: 73-74). As a language for hospitality, it usually uses formal language for a series of activities during the tourism process, both in pre-service and in-service process.

\section{Research Method}

This research belongs to descriptive qualitative research since it aims at giving the brief information about language aspects taught in EfT class as the basis to develop the appropriate language assessment in EfT class. The subjects of the research are the Chief of English education Department of Universitas Ahmad Dahlan, the tourism lecturers' team, the students of EfT class and the partners of Practicum on Tourism.

Then, the procedures conducted in this research are adopted from Hancock and Algozzine's concept (2006: 15) which covers the research preparation, references gathering, the research design decision, data collection, data reduction and interpretation, and report of the findings.

In this research, language aspects become the main focus. To gain several data on it, the researcher interviewed the subjects of the research. Then, the researcher analyzed the data by using Miles and Huberman model of data analysis in Yin (2002: 110) which involved gaining the data, reducing the data, displaying the data and drawing conclusions. After analyzing the data, validity techniques were done to make sure that the data really meets the aims of the research and valid. In this case, Yin's (2002: 51) concept was applied. It involved using various data sources, creating the research database, and choosing the data. The last, to guarantee the trustworthiness of the data, the researcher applied triangulation where all of the subjects' voices were accommodated and only the appropriate data were chosen to analyze in the next step.

\section{Findings and Discussion}

\subsection{Findings}

In this part, the researcher describes the result of the data analysis on the needs analysis in EfT class, especially related to the language aspects. It involves the expressions used in the target situation of the tourism industry. The expressions are put in the following Table 1. 
Table.1 Expressions Used in Tourism

\begin{tabular}{|c|c|c|c|}
\hline No & Category & $\begin{array}{l}\text { Expressions } \\
\text { Context }\end{array}$ & Example \\
\hline 1. & $\begin{array}{l}\text { Greeting and Introducing } \\
\text { Someone }\end{array}$ & Meeting with the guests & Hello! My name is ... \\
\hline 2. & Giving Suggestions & Looking for souvenir & You should ... \\
\hline 3. & Describing things & Offering tourism products & $\begin{array}{l}\text { This is a new souvenir } \\
\text { from ... }\end{array}$ \\
\hline 4. & Describing Procedures & Guiding the guests to do something & Firstly, ... \\
\hline 5. & Expressing Politeness & Asking something to the guests & Could you please ... \\
\hline 6. & Giving Jokes & Guiding the guest in the tourism area & Anything funny \\
\hline 7. & Giving Opinion & $\begin{array}{l}\text { Describing the tourism area or other } \\
\text { tourism products }\end{array}$ & In my opinion, \\
\hline 8. & Offering Something & Offering products & Will you buy ...? \\
\hline 9. & Giving advice & $\begin{array}{c}\text { Guiding the guests in shopping and } \\
\text { praying }\end{array}$ & Better you ... \\
\hline 10. & Asking for apologize & Handling complaints & I'm truly sorry... \\
\hline 11. & Asking permission & Need to go to the toilet, mosque, etc & May I ... \\
\hline
\end{tabular}

\section{1) Greeting and Introducing Someone}

The subjects of this research mentioned that Greeting and Introducing someone are important aspects for tourism communication, especially to begin the conversation. There are various examples of the expressions, for example, "Hello!", "Hai!”, "I am Sanikem.”, "His name is Paijo.”, etc.

\section{2) Giving Suggestions}

Sometimes, the guests or customers need to know the best choice in buying something. That is why the expressions to give suggestions are needed, such as "You should choose this souvenir because of the quality.", "It will be better for you to buy this one because the color is very nice.", etc.

\section{3) Describing Things}

In offering the tourism products, the owners need to describe the products to the guests or customers. The expressions like "This is a new souvenir from this tourism area.", "This is made of good quality wood from this area.", etc are needed.

\section{4) Describing Procedures}

During the tourism activities, the guides usually need to inform the guests the way how to do something, such as entering the temple area. The examples are "To enter the temple, firstly, you have to wear 'jarik' provided by the staff.", "Then, you should walk to the main temple through the path.".

\section{5) Expressing Politeness}

Tourism industry is a hospitality business where politeness is a must. Thus, some expressions using politeness marks are needed to learn. The examples are "Could you please wait here while I go to the ticket box.", "Would you please use the umbrella to protect your skin from the sunshine?", etc.

\section{6) Giving Jokes}

Tourism is a series of activities. To avoid the guests getting bored, the guide should have a joking skill. There are so many varieties in giving jokes. It can be a kind of games to funny stories.

\section{7) Giving Opinion}

Sometimes, the guests ask the guides' opinion about something. Usually, it happens when they explore a tourism area. For example, the guest asks about the guide's opinion related to the history of 
the tourism area. The expressions that can be used to answer the questions is like "In my opinion, this place was created through a very long history and everyone should respect it."

8) Offering Something

During the visit from the guests, the tourism businessman in every position (travel agent, souvenir seller, guide, etc.) needs to offer the products to the guests. The expressions that can be used is "Will you buy this souvenir?", "Do you need a souvenir, sir?", etc.

9) Giving Advice

If the guests need to choose one from several tourism products, the guide needs to give some advice. For example, he/she can say" "You better choose this one than that one."

\section{0) Asking for Apologize}

After the tourism activities, sometimes the guests give complaints about the services. To handle it, the tourism industry owner can use several expressions, such as "I'm truly sorry for the inconvenience.", "So sorry because of the poor service.", and so on.

\section{1) Asking for Permission}

During the activities, the guide sometimes needs to ask for permission from the guests by saying, "May I go to the toilet first?", "Can I use our ID card for registration?", etc.

\subsection{Discussion}

The research findings show the language aspects in the form of expressions are various. However, those are needed for communication between the tourism industry owner and the guests or consumers. Based on the data, the expressions can be divided into two, pre-service and on-service expressions.

Pre-service expressions are language expressions needed during oral marketing, for example when the guests come to the tour agent office to get some information about certain tourism products. It involves greeting, offering, giving opinion, etc. On the other hand, on-service expressions are used while the tourism industry owner gives services to the guests. Both of them are important and should run well so that the aims of tourism can be reached well.

\section{Conclusion}

EfT class involves language and tourism aspects in its instructional process. In order to make sure that the instructional process can run like a charm, the instructional design should analyze the needs. The needs are divided into two, learner needs and learning needs. In this occasion, the focus is the learner's needs. From the research, pre-service and On-service expressions are identified to be put as the priority in developing the appropriate materials for EfT class.

\section{References}

Blue, G. M., and Harun, M. (2003). Hospitality language as a professional skill. English for specific purposes, 22. pp. 73-91. ISSN 0889-4906

Cahyo, S.D., Muslim, M.R.U., Rahman, A.N., \& Pratolo, B.W. (2019). Needs analysis of Islamic-based English reading material for the Muhammadiyah junior high school. International Journal of Evaluation and Research in Education, 9(2), 286-292.

Damanik, J. dan Weber F. H. (2006). Perencanaan ekowisata: Dari teori ke aplikasi. Yogyakarta: Andi Offset.

Day, J., \& Krzanowski, M. (2011). Teaching English for specific purposes: An introduction. Cambridge: Cambridge University Press.

Fatimah N. (2018). Students' needs for academic writing at the English Education Department. English Language Teaching Educational Journal, 1(3), 161-75.

Hancock, D. R, and Algozzine, B. (2006). Doing case study research. New York: Teachers College Press. pp.15-17.

Hutchinson, T., and Waters, A. (1987). English for specific purposes: A learning-centered approach. Cambridge: Cambridge University Press. 
Kusumawati, F. (2018). Developing English for Specific Purposes (ESP) Module for Computer Science Students Vocabulary Mastery. English Language Teaching Educational Journal, 1(1), 13-21. doi:https://doi.org/10.12928/eltej.v1i1.142

Mahendra, A. (2020). Constructing identity: Experiences of Indonesian ESP teachers in a language institute. English Language Teaching Educational Journal, 3(3), 229-240. doi:https://doi.org/10.12928/eltej.v3i3.2560

Prachanant, N. (2012). Needs analysis on English language use in tourism industry. Procedia-Social and Behavioral Sciences, 66: 117-125

Richards, J. C. (2001). Curriculum development in language teaching. Cambridge: Cambridge University Press.

Sholikhi, F. (2020). Edmodo use in ESP writing: The perceptions and barriers of sociology students. English Language Teaching Educational Journal, 3(3), 241-253. doi:https://doi.org/10.12928/eltej.v3i3.2402

Yin, R. K. (2002). Case study research: Design and methods. California: SAGE Publications. 